\title{
CATERPILLARS IN PASTURE
}

By C. M. BLICK, Fields Instructor, Department of Agriculture, Warkworth.

In March 1952 an outbreak of destructive caterpillars caused severe damage to pastures in parts of the North Auckland Peninsula. Hordes of these caterpillars with ravenous appetites. completely defoliated pastures in a few days and caused considerable losses to some farmers.

The caterpillars were identified as the larvae of the moth Leucania unipuncta, which are commonly known as army worms because of their habit of gathering into huge numbers and moving across fields together, devouring all pastures and destroying crops in their path.

There have been several infestations by this or closely related army worms reported in New Zealand. Pastures were attacked in the Ashburton County in Canterbury in 1933,. in the Opotiki district and North Auckland in 1938, and last year maize was attacked in the Gisborne area. The 1952 attack in North Auckland was therefore the first time that caterpillars had occurred in outbreak numbers in New Zealand since the advent of DDT. There are no reports of insecticides bemg used for control in this country before 1952, although in other countries paris green baits were used before DDT was available.

The same caterpillar appears in destructive numbers much more frequently in Australia, where it is associated with heavy rains, floods, and an abundance of grass. In the United States of America this particular caterpillar is considered of major economic importance, being the most troublesome of the numerous army worms.

There are four stages in the development of Leucania unipuncta: the egg stage, the larva or caterpillar,, the pupa or resting stage, and the adult moth. The moth tends to be rather short with a wing expanse of up to l.5in. The wings are brownish grey and the moth may be distinguished by the presence of a small white spot in the centre of each fore wing. The hind 
wings tend to be darker toward the outer extremities.

The moth is a night-flying species. It rests during the day and toward dusk emerges and is strongly attracted to lights. A single moth is capable of laying several hundred eggs and these are usually deposited on the leaves of grasses. The eggs hatch in a week or ten days, more or less depending on temperatures. There emerges a greenish caterpillar which is so small that, although there may be many thousands of them, they escape notice. They have comparatively small appetites and their habit of hiding during the day and feeding at night means that they are usually unnoticed at this stage. The caterpillars are usually greenish-gray with light longitudinal stripes along the sides and an almost black stripe along the centre of the back. A length of $1 \frac{1}{2}$ in. may be reached by the time the caterpillar is fully grown and at this stage it will pupate either just below the ground surface or on the surface beneath clods or debris. It is at this stage that the adult characteristics are acquired and the adult moth emerges after a period depending on seasonal conditions. The life cycle of this insect in New Zealand has not been investigated in detail so that it is not known in what form it is carried over the winter. In July of this year both immature caterpillars and pupae were found, although there were many more of the latter.

The exact cause of the periodic outbreaks is not known, but a number of theories have been put forward. The outbreaks invariably occur after flooding and in the recent infestation damage was almost entirely confined to areas which were flooded for a number of days. Slightly elevated areas where flood water receded quickly and which were under water for hours were not usually affected. One theory is that the eggs washed from the catchment area are held in suspension by the flood waters; In low-lying areas where the water backs up and is sluggish the eggs are dropped from suspension and give rise to heavy infestations. It has also been suggested that parasites of the insect are destroyed by floods, and that the moist, humid conditions which follow flooding are favourable to the hatching and survival of the young caterpillars. Overseas experience indicates that the moths congregate in numbers for the egg laying and that they seek moist positions for this activity. If the subsidence of the floods coincided with the period when the moths were on the wing, it would be 
likely that they would be attracted to these areas and deposit large numbers of eggs.

A first visit to an infested field is most impressive. The colossal number of. caterpillars present is almost unbelievable. It was impossible to obtain a count in the heavily infested areas, but it was estimated that there were at least ' 75 per sq. ft., or $3,000,000$ per acre, and each -has a tremendous appetite. F'aspalum was the dominant constituent of pastures at the time and the caterpillars found this grass very palatable; clovers and Lotus species were eaten with more reluctance and were not generally touched until feed became short. Rushes were also eaten, the outside green casing of the leaves being stripped off, leaving only a white membraneous tissue. As the infestation proceeded pastures became eaten out and completely devoid of green leafage, but even so the caterpillars did not mass together and march in search of food as they so often do in other countries. There was little movement from the source of original infestation,

Two methods of control were evolved. Mr C. E. Ballinger, Instructor in Agriculture, Whangarei, carried out trials using DDT and BHC as dusts and at Warkworth DDT baits were tried. Both methods gave very satisfactory control. In the dusting trials treatments consisted of $\frac{1}{2} \mathrm{lb}$. and $11 \mathrm{~b}$. of 100 per cent DDT and $\frac{1}{4} \mathrm{lb}, \frac{1}{2} \mathrm{lb}$. and $\mathrm{llb}$. of 100 per cent BHC. The BHC was applied in the form of "Agrocide 7" which contains 2.6 per cent of gamma isomer benzine hexachloride. These quantities were mixed with fertiliser and the mixture applied-through a rotary topdresser at $100 \mathrm{lb}$. per acre. Twenty-four hours after application the caterpillars were still very active, but after '72 hours a satisfactory kill had been obtained. In the bait trials at Warkworth it was intended to use bran as a basis, but as it was not available, poultry mash was substituted. Good kills were obtained from applications of, bait consisting of $251 \mathrm{~b}$. of poultry mash, $41 \mathrm{~b}$. of molasses, and 1/10lb. of, DDT per acre. However, in some instances where infestation was particularly heavy these quantities were insufficient to provide each-caterpillarwith-a-dose; -Thirty-five-pounds of poultry mash, 5lb. of molasses, and $\frac{1}{81} \mathrm{lb}$. of DDT per acre gave almost 100 per cent kills within 24 hours on heavily infested fields. To reduce the cost of the bait, sawdust was substituted for the poultry mash. A bait consisting of $501 \mathrm{~b}$. of sawdust, $7 \mathrm{lb}$. of molasses, and 1/10 lb. of DDT proved successful on a field which 
was only lightly infested. Counts on this field 24 hours after application showed a reduction from 20 per sq. ft. to 4 per sq. ft.

Experience showed that the baits should be fairly dry, as wet baits were difficult to spread evenly. A dry bait can be spread through a topdresser, although this method was not used during the recent outbreak. It is preferable to sow the baits during the late afternoon so that they remain fresh and attractive for the caterpillars, which are not usually active until the evening. Whether it be a dust or a bait that is to be mixed, great care should be exercised to ensure that the small amount of insecticide is thoroughly incorporated throughout the mix. A concrete mixer has been found useful for this work.

Dusting is a more expensive method of control than baits. The $\frac{1}{2} \mathrm{lb}$. of DDT per acre required for dusting costs about 12s 6d.; "Agricide ' 7 " at $8 \frac{1}{2} \mathrm{lb}$. per acre costs $12 \mathrm{~s}$. $5 \mathrm{~d}$. The sawdust bait would cost about $5 \mathrm{~s}$. per acre plus the cost of cartage of the sawdust. The baits also have the advantage of giving more rapid results and being less affected by rain than the dusts.

It does not appear likely that we will ever be able to prevent army worm attacks, so that it remains for us to be able to identify attacks early and bring them under control before serious damage is done. Those farming in areas subject to flooding should be on the alert after summer floods and, by using one of the control methods mentioned, it should be possible to prevent severe damage.

\section{DISCUSSION}

Q. My experience suggests that the pest is carried down from swampy headwaters of rivers and that control could be carried out there.

A. If the theory that eggs are collected at swampy headwaters and carried down is correct, control there might be worth inquiring into. Moths are attracted to damp areas. If there is little growth on pastures they would not be so attractive, as they would dry out quicker than longer.

lusher growth, which would remain attractive to moths

Q. Is there any other evidence to suggest that invasion follows flooding?

A. Infestations in 1938 in Opotiki and at the same time in North Auckland and in 1952 all followed floods.

Q. What time should it be controlled in maize crops and is the pest known as the cutworm? 
A. Control as soon as you see it. Baits are not so satisfactory in maize crops. The caterpillar tends to live on the maize itself rather than on the ground, so that dusting would give better control. There are many species of cutworm. The caterpillar does adopt cutworm tactics. Those caterpillars that come after flooding scarcely move above the area flooded. Caterpillars come out in the afternoon. Then use the dust, which with a faint breeze will spread widely. farmers appear more willing to mix the bait with fertiliser than with mash.

A. (Hamblyn): The attack on maize in Poverty Bay was not the result of flooding. Control was effected there very well by aerial dusting. It was a very wet season. I have seen quite considerable areas of maize eaten out and adjoining pastures then attacked by army worms on the move.

Q. As floods. subsided I have noticed a red worm eating the inside right out of caterpillars.

A. (Blick) I didn't observe such an insect, but did notice caterpillars eating parts of those already killed by baits, so that the one bait dose might be responsible for a number of deaths. 